\title{
Christian-Muslim Relations.
}

A Bibliographical History

Volume 6. Western Europe (1500-1600)

Edited by David Thomas and John Chesworth

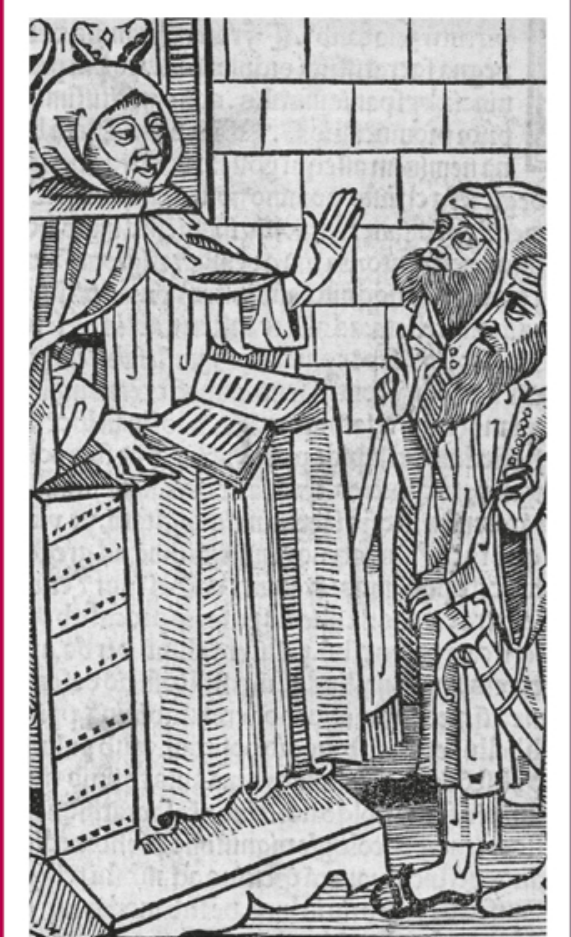

With

John Azumah

Stanisław Grodź

Andrew Newman

Douglas Pratt

B R I L L 
Christian-Muslim Relations

A Bibliographical History 


\title{
History of Christian-Muslim Relations
}

\author{
Editorial Board \\ David Thomas, University of Birmingham \\ Sandra Toenies Keating, Providence College \\ Tarif Khalidi, American University of Beirut \\ Suleiman Mourad, Smith College \\ Gabriel Said Reynolds, University of Notre Dame \\ Mark Swanson, Lutheran School of Theology at Chicago
}

\section{Volume 22}

Christians and Muslims have been involved in exchanges over matters of faith and morality since the founding of Islam. Attitudes between the faiths today are deeply coloured by the legacy of past encounters, and often preserve centuries-old negative views.

The History of Christian-Muslim Relations, Texts and Studies presents the surviving record of past encounters in authoritative, fully introduced text editions and annotated translations, and also monograph and collected studies. It illustrates the development in mutual perceptions as these are contained in surviving Christian and Muslim writings, and makes available the arguments and rhetorical strategies that, for good or for ill, have left their mark on attitudes today. The series casts light on a history marked by intellectual creativity and occasional breakthroughs in communication, although, on the whole beset by misunderstanding and misrepresentation. By making this history better known, the series seeks to contribute to improved recognition between Christians and Muslims in the future. 


\title{
Christian-Muslim Relations A Bibliographical History
}

\author{
Volume 6. Western Europe (1500-1600)
}

\author{
Edited by \\ David Thomas and John Chesworth \\ with John Azumah, Stanisław Grodź, \\ Andrew Newman, Douglas Pratt
}

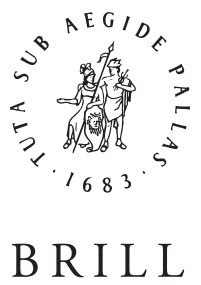




\section{Arts \& Humanities Research Council}

Cover illustration: This is the title page of an edition of Riccoldo da Monte di Croce's (d. 1320) Improbatio alcorani (also known as Contra legem Saracenorum), published in Seville on 20 March, 1500 (Houghton Library, Harvard University, Typ Inc 9543.5). The illustration shows Spanish Muslims listening under duress to a sermon from a Christian preacher, part of the requirements forced on them in the aftermath of the fall of Granada in 1492 (reproduced with permission from Houghton Library, Harvard University).

Library of Congress Cataloging-in-Publication Data

Christian Muslim relations : a bibliographical history / edited by David Thomas and John Chesworth; with John Azumah... [et al.].

p. cm. - (The history of Christian-Muslim relations, ISSN $1570-735^{0}$; v. 22) Includes index.

ISBN 978-90-04-25073-4 (hardback : alk. paper) 1. Christianity and other religionsIslam. 2. Islam-Relations-Christianity. 3. Christianity and other religions-IslamBibliography. 4. Islam—Relations—Christianity—Bibliography. I. Thomas, David.

II. Chesworth, John III. Azumah, John. IV. Title. V. Series.

BP172.C4196 2009

$016.2612^{\prime} 7$ - dc22

2009029184

This publication has been typeset in the multilingual "Brill" typeface. With over 5,100 characters covering Latin, IPA, Greek, and Cyrillic, this typeface is especially suitable for use in the humanities. For more information, please see www.brill.coml/brill-typeface.

ISSN 1570-7350

ISBN 978-90-04-25073-4 (hardback)

ISBN 978-90-04-28111-0 (e-book)

Copyright 2014 by Koninklijke Brill NV, Leiden, The Netherlands.

Koninklijke Brill NV incorporates the imprints Brill, Brill Nijhoff, Global Oriental and Hotei Publishing.

All rights reserved. No part of this publication may be reproduced, translated, stored in a retrieval system, or transmitted in any form or by any means, electronic, mechanical, photocopying, recording or otherwise, without prior written permission from the publisher.

Authorization to photocopy items for internal or personal use is granted by Koninklijke Brill NV provided that the appropriate fees are paid directly to The Copyright Clearance Center, 222 Rosewood Drive, Suite 910, Danvers, MA 01923, USA.

Fees are subject to change.

This book is printed on acid-free paper. 


\section{CONTENTS}

Foreword _........................................................................................... vii

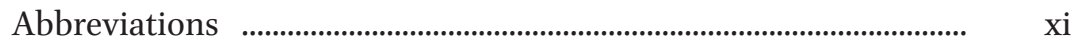

Martha Frederiks, Introduction: Christians, Muslims and empires in the $16^{\text {th }}$ century ...............................................................................

Nabil Matar, The Qur'an in English writings, 1543-1697 ……………...... 11

Thomas E. Burman, European Qur'an translations, 1500-1700 ……..... $\quad 25$

Works on Christian-Muslim relations 1500-1600 …………………….. 39

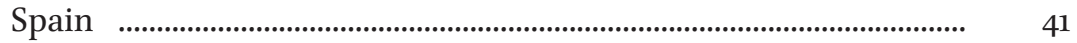

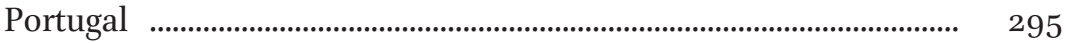

Italy and Malta

France and Northern Europe $\quad$.................................................................. 603

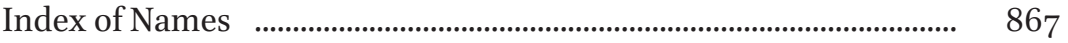

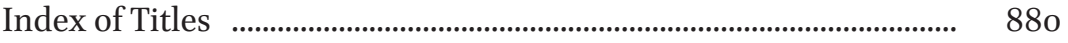




\title{
Luís Vaz de Camões
}

\author{
Camões \\ DATE OF BIRTH Approximately 1524 \\ PLACE OF BIRTH Probably Lisbon or Coimbra \\ DATE OF DEATH 10 June 1580 \\ PLACE OF DEATH Lisbon
}

\section{BIOGRAPHY}

Luís Vaz de Camões is considered the greatest poet of the Lusophone countries because of the influence he had on the Portuguese language. His biography is richer in anecdotes than facts, and even the details of his birth are uncertain.

It is assumed that Camões was born in Lisbon or Coimbra in around 1525. According to one tradition, he attended courses in the humanities at the University of Coimbra, although without being registered. This may, in fact, be accurate, as from 1542 his uncle, the Augustinian Bento Camões, was chancellor of the university. After his return to Lisbon, he frequented court circles and encountered the new culture in which the classical tradition came into interaction with Italian and Castilian.

In about 1547, Camões first experienced Christian-Muslim confrontation when, in the course of a battle against the Moors at Ceuta in Morocco, he was injured and lost the vision in his right eye. Back in Lisbon, he was imprisoned from 16 June $155^{2}$ to 13 March 1553 for brawling. In 1553, he sailed to Goa and remained in the East for more than 15 years, working as a public official as well as taking part as a soldier in at least two military missions. During this time, he was again sent to prison twice, first in Macao then in Mozambique.

It was during this time in the East that Camões worked on Os Lusíadas, which he published in 1572 , two years after his return to Lisbon. He died in Lisbon in 1580 , aged 56.

\section{MAIN SOURCES OF INFORMATION}

\section{Secondary}

J.H. Saraiva, Vida ignorada de Camões, Lisbon, 1978

J. Nabuco, The Lusiads as the epic of love, Ithaca NY, 1909 


\section{WORKS ON CHRISTIAN-MUSLIM RELATIONS}

\section{Os Lusíadas, 'The Lusiads'}

\section{DATE 1572}

ORIGINAL LANGUAGE Portuguese

\section{DESCRIPTION}

Os Lusíadas is an epic work, generally ranked among the masterpieces of world literature. Its title comes from Lusíadas, 'Portuguese', deriving from the Roman name for Portugal, Lusitania. It describes the explorations of the Portuguese and the voyage of Vasco da Gama on his discovery of the route to India, and it is also an account of the intense battle of Catholic Christendom against the advance of Islam, especially in its Sunni form. Camões's verses reveal the hatred of the Christians for the Moors, whom they regard as heretics. He reiterates the typical classical Portuguese idea from the age of discoveries, that the ultimate goal of the activities in the Indies was the conquest of Egypt, the liberation of the Holy Land from Muslim rule, and the destruction of the holy sites in Mecca and Medina. In India, the Portuguese met a plethora of Islamic peoples, while at the same time they were confronting the Ottoman Empire and potentially seeking agreements with the Safavid rulers of Persia. During the $16^{\text {th }}$ century, the earlier call for a cruzada ('crusade') became a rhetorical formula that was frequently employed but rarely led to large-scale military mobilisation against the Ottomans. Like many other early modern European men of letters, Camões demanded an all-out war against the 'Turk'.

The ideological axis of the poem focuses on the relationship of Portugal with the Islamic world, depicted as a just war waged against Islam. As Camões suggests, one cannot forget 'the great valour of that brave people the Portuguese', who 'have expelled the Muslim, for all his strength and numbers, from the entire region of the Tagus' (Canto I:42).

Os Lusíadas consists of ten cantos, which celebrate the defeat of Islam and the spread of Christianity through the southern hemisphere to South-East Asia. Each canto is composed in a variable number of stanzas (1,102 in total), which are based upon the decasyllabic ottava rima (rhyme scheme: ABABABCC). The narration, written in Homeric fashion, begins with the voyage of Vasco da Gama and ends with his return from India. Inserted into this narrative, it tells the history of Portugal (Canto III).

In the introduction, Camões, showing his classical background, pays homage to Virgil and Homer, and describes the ancient Greek gods. 
Throughout, he creates a fusion of pagan, Christian and Islamic symbolism. Thus, in Canto II Vasco da Gama, who is in Mombasa, sends two convicts to assess the situation around the Portuguese group. An ambush has been set by the local Muslim king, but the goddess Venus and the Nereids intervene to help the Portuguese overcome the Moorish trick. Venus symbolises the higher purpose of the epic adventure, and also the redeeming essence of Christianity. In opposition to this, starting in Canto I, Bacchus represents the obstacle standing in the way of Christianity. He is the Lord of India, who fears having his power usurped by the Christian Portuguese, and also of the infidels, who must be redeemed.

Camões dedicated the poem to the young King Sebastian of Portugal, who was aged 24 at the time. A few days after the famous battle of Lepanto on 7 October 1571, in which European naval forces defeated the powerful Ottoman fleet, Camões invited King Sebastian to attack Morocco, using the mythological language of his own Ecloga, titled Que grande variedade $v \tilde{a} o$ fazendo. According to Vitor Aguiar e Silva, it is possible that King Sebastian was influenced in his crusade by these great poetic words. King Sebastian was killed on 4 August 1578 at al-Qașr al-Kabīr, in Morocco.

Camões's poem could be said to have contributed to the creation of 'Sebastianism', a popular national belief that the monarch was not really dead but had only disappeared, to one day return, reclaim the throne and fill the world with justice, a legend that shares commonalities with the Islamic belief in the Mahdī, who would appear to restore justice and righteous rule.

\section{SIGNIFICANCE}

Os Lusíadas shaped the Portuguese attitude towards Muslims. It portrays Islam, particularly as represented by the Turks, not only as heretical but also as the belief of the enemies of Catholic Portugal. Thus, Muslims must be defeated for Christianity finally to triumph in East and West.

This epic poem has exerted great influence in shaping Portuguese language and literature, with the consequence that the sentiments expressed in it towards Muslims and Islam have continued to influence the attitudes of Lusophones to the present day.

\section{MANUSCRIPTS}

The assessment of the manuscript tradition is still a matter of dispute among scholars.

\section{EDITIONS \& TRANSLATIONS}

Os Lusíadas has appeared in many editions and translations. Below is a selected list reflecting its influence. 
Z. Trzeszczkowska (trans.), Luzjady. (Os Lusíadas). epos w dziesięciu pieśniach, Sandomierz, Poland, 2013 (Polish trans.)

Os Lusíadas, ed. R. Arnold, trans. H.-J. Schaeffer, Darmstadt, 2010 (German trans.)

L.V. de Camões, Obra completa, ed. A. Salgado Jr, Rio de Janeiro, 2003

H. Barrilaro Ruas (ed.), Os Lusíadas, Lisbon, 2002

O. Gomes (trans.), Lujhitāyaṇa, Goa, 2003 (Konkani trans.)

R. Averini (trans.), I Lusiadi, Milan, 2001 (Italian trans. with parallel Portuguese text)

S. González (trans.), Os Lusíadas, Madrid, 1990 (Asturian trans.)

O. Ovcharenko (trans.), Luziady; Sonety, Moscow, 1988 (Russian trans. of Os Lusíadas and the Sonnets)

Os Lusiadas, Sao Paulo, 1982

Đ. Šaula (trans.), Luzijadi, Belgrade, 1981 (Serbian trans.)

Hideo Kobayashi (trans.), Uzu rujiadasu: rushitania no hitobito, Tokyo, 1978 (Japanese trans.)

A. Capuder (trans.), Luzijada. Izbor, Ljubljana, 1976 (selected excerpts in Slovenian)

F. Pierce (trans.), Os Lusíadas, Oxford, 1973 (English annotated trans.)

A. Covaci (trans.), Lusiada, Bucharest, 1965 (Romanian trans.)

G. Colom and M. Dolç (trans.), Els lusíades, Barcelona, 1964 (Catalan trans.)

K. Bednár (trans.), Lusovci, Prague, 1958 (Czech trans.)

R. Bismut (trans.), Les luciades de Luis de Camões, Lisbon, 1954 (French trans.)

W.C. Atkinson (trans.), The Lusiads, London, $195^{2}$ (English trans.)

Os Lusíadas, $3^{\text {rd }}$ edition, Porto, 1933

J. Vrchlický (trans.), Lusovci (Os Lusiadas). báseň o desíti zpěvech, Prague, 1902 (abridged Czech trans.)

F. de Santo Agostinho Macedo (trans.), A lusiada de Luiz de Camões. Traduzida en versos latinos, Paris, 1890 (Latin trans.)

The Lusiad of Luis de Camoens, London, 1853 (English trans.)

J.J.C. Donner (trans.), Die Lusiaden, Stuttgart, 1833 (German trans.)

L. Stoppendaal (trans.), De Lusiade. heldendicht in X zangen, Antwerp, 1777 (Dutch trans.)

W.J. Mickle (trans.), The Lusiad, or, The discovery of India. An epic poem, Oxford, 1776 (English trans.) 
N.N. Piemontese (trans.), La Lusiadi. o sia la scoperta delle Indie Orientali, Turin, 1772 (Italian trans.)

M. Duperron de Castera (trans.), La lusiade de Camoens. Poeme heroique, sur la decouverte des Indes Orientales, Amsterdam, 1735 (French trans.)

M. de Faria i Sousa (trans.), Os Lusiadas, Madrid, 1639 (Spanish trans.)

Os Lusiadas, Lisbon: Casa de Antonio Go[n]çaluez impressor, 1572 STUDIES

There are numerous scholarly works on the Lusíadas. Those that deal with Islam include:

V. Aguiar e Silva (ed.), O Dicionário de Luís de Camões, Alfragide, Portugal, 2011

C. Willis, Camões, prince of poets, Bristol, 2010

M.L. de Castro Soares, 'A aventura do amor e do espírito. A lírica e a epopéia de Camões', in M.L. de Castro Soares (ed.), Tendências da literatura. Do Classicismo ao Maneirismo e ao Barroco e sua projecção na actualidade, Vila Real, Portugal, 2009, 88-97

M.L. de Castro Soares, Profetismo e espiritualidade de Camões a Pascoaes, Coimbra, 2007, pp. 74-84

N. Bisaha, Creating East and West. Renaissance humanists and the Ottoman Turks, Philadelphia PA, 2004

F.F. Moreira, Visão do amor e do homem. Uma análise lingüísticoestilística de oitavas rimas do Camões e de um soneto de Cruz e Souza, Maceió, Brazil, 2005

M. Cavalcante, Por mares muito antes navegados. A tradição de Camões na poesia colonial brasileira, Bairro, Brazil, 2001, p. 73

M. de Lourdes Abreu de Oliveira, Eros e tanatos no universo textual de Camões, Antero e Redol, Pinheiros, Sao Paulo, 2000, pp. 20-31

R. Finlay, 'Portuguese and Chinese maritime imperialism. Camões's Lusiads and Loo Maodeng's Voyage of the San Bao eunuch', Comparative Studies in Society and History 34 (1992) 225-41

H.H. Hart, Luis de Camoëns and the epic of the Lusiads, Norman OK, 1962

Nicola Melis 